JOURNAL OF HEALTH SCIENCE AND PREVENTION

http://jurnalfpk.uinsby.ac.id/index.php/jhsp

ISSN 2549-919X (e)

\title{
Factors Associated with the Selection of Contraception Devices in Fertile Age Couples in Tabang Village Bolong Village North Walenrang Districh Luwu Regency in 2016
}

\author{
Hera Wati Ramli' ${ }^{1}$, Syafitrah Oktavianti Muhli' \\ 1.2S1 Nursing study program, Kurnia Jaya Persada College of Health Sciences \\ Correspondence: herawatiramli19@gmail.com
}

DOI: http://doi.org/10.29080/jhsp.v3i1.291

\begin{tabular}{l} 
Keywords \\
\hline Lushage couple \\
Husband support \\
Knowledge \\
Education \\
Type of \\
contraception
\end{tabular}

\begin{abstract}
Factors Associated with the Selection of Contraception Devices in Fertile Age Couples in Tabang Village, Bolong Village, North Walenrang District, Luwu Regency, 2016. This study aims to analyze the factors related to respondents. Where the theory that explains there are several factors that can influence the selection of the tools that most influence are fundamental things. This research was conducted in Tabang Hamlet, Bolong Village, North Walenrang District, Luwu Regency using cross- sectional study method. The population in this study were 30 couples in the suburbs (PUS) who used contraception in Tabang Village, Bolong Village, North Walenrang District, Luwu Regency. The sampling technique in this study used total sampling. Data collection through data demographics and questionnaires, data analysis using Chi-Square Test. The results of the study showed that most respondents chose injectable contraceptive methods. There is a very effective relationship between the values with contraceptive selection $p$ value $=0.00$ (5 0.05), there is a relationship between knowledge and with the choice of toxicity $p$ value $=0.01$ (5 0.05), and there is a relationship that means between education with contraceptive selection $p$-value $=0.01$ ( $\leq 0.05$ ). From this study, knowledge and education were the most effective factors in the factors related to the selection of contraception devices in fertile age couples (Pus) in Tabang Village, Bolong Village, North Walenrang District.
\end{abstract}

\section{Introduction}

Indonesia is a developing country with a population of $252.124,458$ with an area of $1,913,378.68 \mathrm{~km} 2$ and a population density of 131.76 people/ $\mathrm{km} \mathrm{2[1].} \mathrm{One} \mathrm{of} \mathrm{the} \mathrm{problem} \mathrm{found} \mathrm{in} \mathrm{Indonesia} \mathrm{is} \mathrm{the} \mathrm{relatively} \mathrm{high}$ rate of population growth. The estimated middle population (2013) is 248.8 million people with a population growth rate of $1.48 \%$. The rate of growth determined by birth and death in the presence of improvements in health services causes low mortality rates, while the birth rate remains high, the main cause of the population explosion. Then, the population was emphasized by promoting Family Planning (KB)[2].

The use of contraceptive methods is of particular concern at this time, the 2013 National Medium Term Development Plan (RPJMN) survey shows the condition that PUS (fertile age couples) are aware of all modern contraceptives, such as IUD (Intra Uterine Device)/UD. Spiral, MOP (Male Operating Method), MOW (Female Operation Method), Implants, Injectables, birth control pills, and condoms are only $10.6 \%$. This means that still $80.4 \%$ of PUS do not know all modern contraceptives and those who know of at least 6 
(six) types of modern contraception are only 59.2\%. On the other hand, EFA who knows all the methods or methods of family planning (IUD / IUD / Spiral, MOP, MOW, and Implant) were only $40.2 \%$. This means that there are still around $59.8 \%$ of EFA who do not know all types of contraception.

The population of South Sulawesi based on DAU in 2014 amounted to 8,432,163 people spread in 24 regencies/cities, with the largest population being 1,429,242 inhabiting Makassar City. Overall, the population of women is more than the population of male sex, this is reflected in the number of sex ratios smaller than 100. Only in the area of Enrekang Regency, TanaToraja, North Luwu, East Luwu, and North Toraja which shows the sex ratio is greater than 100, which means that the male population in the two regions is greater than the female population Palopo City is in fifth place from all districts/ities in South Sulawesi because of its success in suppressing the population growth rate. This is due to the awareness of Fertile Age Couples (PUS) in Palopo City with family planning increased in 2016. According to the Head of the Community Empowerment and Family Planning Agency (BPMP-KB) of Palopo City, as many as 15,507 Fertile Age Couples (PUS) in the City area Palopo have joined the Family Planning (KB) program. Based on available data, up to this August PUS in Palopo City increased by 10 percent from 2015. PUS in Palopo City as of August reached 22,821 couples. Whereas in 2015 the number of PUS was 21,980 pairs.

According to research from Anita Lontaan, entitled Factors Related to the Selection of Fertile Age Couples Contraception in Damau Health Center, Talaud District. The results showed that most respondents chose non-long-term contraception methods[3]. Factors of socio-economic, education, husband/wife participation, age have a relationship with contraceptive selection, and parity factors have no relationship with contraceptive selection. The conclusion of this study that the factors that have a relationship with the selection of contraception are socio-economic $(\rho=0.000)$, education $(\rho=0.000)$, husband / wife participation $(\rho=0.000)$, age $(\rho=0.0520)$, factor parity $(\rho=0.726)$ has no relationship with contraceptive selection.

From the results of a survey of writers in Tabang Village, Bolong Village, the total number of acceptors in Bolong Village, North Walenrang District, 2017 in the selection of contraceptive methods was 30 acceptors. The author conducted interviews with 5 acceptors regarding the selection of contraceptive methods and found that almost all of them were not appropriate in choosing contraceptive methods. From the results of the interview, the writer can draw conclusions on several factors that might influence respondents in choosing the type of contraception used, including factors of husband's support, knowledge and education. From the background above, the authors are interested in conducting further research regarding Factors Associated with the Selection of Contraception Devices in Fertile Age Couples (PUS) in Tabang Hamlet, Bolong Village, North Walenrang District, 2017 Luwu Regency.

\section{Methods}

The type of research used in this study is a cross-sectional design where data concerning independent and dependent variables will be collected at the same time. This cross-sectional study aims to determine the factors associated with the selection of contraceptives in couples of childbearing age in Tabang Des Hamlet. BolongKec. North Walenrang in 2017. The population is 30 people of childbearing age, with a sample of the entire population with a total sampling technique. Research instruments used questionnaires in the form of checklists containing questionnaires and accompanied by demographic data. Where data collection procedures consist of promoter and secondary data and pass several data processing processes.

\section{Results}

Univariate analysis

The distribution of respondents based on husband's support.

Table 1

Frequency Distribution of Respondent Characteristics According to Husband's Support to the Selection of Contraception

\begin{tabular}{ccc}
\hline Husband support & Frequency & Percentage \\
\hline Disagree & 7 & 23.3 \\
Agree & 23 & 76.7 \\
\hline Total & 30 & 100.0 \\
\hline
\end{tabular}

Sumber: Data primer 2017 
Table 1 shows that out of 30 respondents, couples who did not receive husband support used contraceptives as many as 7 respondents (23.3\%) and those who received husband support were 23 respondents $(76.7 \%)$

Distribution of respondents based on level of knowledge

Table 2

Frequency Distribution of Respondent Characteristics According to Knowledge Leve

\begin{tabular}{ccc}
\hline Knowledge & Frequency & Percentage \\
\hline Less & 6 & 20.0 \\
Good & 24 & 80.0 \\
\hline Total & 30 & 100.0 \\
\hline
\end{tabular}

Source: 2017 primary data

Table 2 shows that out of 30 respondents, respondents with less knowledge of contraception were used as many as 6 respondents (20.0\%) while those with good knowledge were 24 respondents $(80.0 \%)$

Distribution of respondents based on education level

Table 3

Frequency Distribution of Characteristics of Respondents by Education

\begin{tabular}{ccc}
\hline Education & Frequency & Percentage \\
\hline Basic & 6 & 20.0 \\
Middle & 24 & 80.0 \\
\hline Total & 30 & 100.0
\end{tabular}

Source: 2017 primary data

Table 3 shows that out of 30 respondents, respondents with basic education level were 6 respondents $(20.0 \%)$ while respondents with secondary education level 24 respondents $(80.0 \%)$.

The distribution of respondents based on type of contraception.

Table 4

Frequency Distribution of Respondent Characteristics by Type of Contraception

\begin{tabular}{ccc}
\hline Contraception & Frequency & Percentage \\
\hline Pill & 11 & 36.7 \\
Injection & 19 & 63.3 \\
\hline Total & 30 & 100.0 \\
\hline
\end{tabular}

Source: 2017 primary data

Table 4 shows that out of 30 respondents, according to the type of contraception used by respondents with the selection of contraceptive methods as many as 11 respondents who chose the pill (36.7\%) and most chose injection contraception as many as 19 respondents (63.3\%).

Analysis bivariat

The relationship of husband's support to the selection of contraceptives.

Table 5

Relationship with Husband Against the Selection of Contraception Devices in Fertile Age Couples (PUS)

\begin{tabular}{|c|c|c|c|c|c|c|c|}
\hline \multirow{3}{*}{ Husband Support } & \multicolumn{4}{|c|}{ Contraception } & \multicolumn{2}{|c|}{ Total } & \multirow{3}{*}{$\begin{array}{c}\text { P. } \\
\text { Value }\end{array}$} \\
\hline & \multicolumn{2}{|c|}{ Pil } & \multicolumn{2}{|c|}{ Suntik } & \multirow[b]{2}{*}{$\mathrm{N}$} & \multirow[b]{2}{*}{$\%$} & \\
\hline & $\mathrm{N}$ & $\%$ & $\mathrm{~N}$ & $\%$ & & & \\
\hline Disagree & 7 & $23 \%$ & 0 & $0.0 \%$ & 7 & $23.3 \%$ & \\
\hline Agree & 4 & $13.3 \%$ & 19 & $63.3 \%$ & 23 & $76.7 \%$ & \\
\hline Total & 11 & $36.7 \%$ & 19 & $63.3 \%$ & 30 & $100.0 \%$ & \\
\hline
\end{tabular}

Source: 2017 primary data 
Table 5 analysis shows that out of 30 respondents, there were 7 (23.3\%) respondents who did not receive husband's support using pill type contraception while 4 (13.3\%) others received husband's support, while those who did not get husband's support using injection type contraception were $0(0.0 \%)$ respondents and those who got husband support using injectable type contraception, there were 19 (63.3\%) respondents.

This means that there is a relationship between husband's support for the selection of contraceptives in couples of childbearing age (pus) in Tabang Village, Bolong Village, Kec. Walenrang Utara Kab.Luwu.

The relationship of respondents' knowledge to the selection of contraceptives.

Table 6

The Relationship between Knowledge and the Selection of Contraception Devices in Fertile Age Couples (PUS)

\begin{tabular}{|c|c|c|c|c|c|c|c|}
\hline \multirow{3}{*}{ Knowledge } & \multicolumn{4}{|c|}{ Contraception } & \multicolumn{2}{|c|}{ Total } & \multirow{3}{*}{$\begin{array}{c}\text { P. } \\
\text { Value }\end{array}$} \\
\hline & \multicolumn{2}{|c|}{ Pill } & \multicolumn{2}{|c|}{ Injection } & \multirow[b]{2}{*}{$\mathrm{N}$} & \multirow[b]{2}{*}{$\%$} & \\
\hline & $\mathrm{N}$ & $\%$ & $\mathrm{~N}$ & $\%$ & & & \\
\hline Less & 6 & $20.0 \%$ & 0 & $0.0 \%$ & 6 & $20.0 \%$ & \multirow{3}{*}{.001} \\
\hline Good & 5 & $16.7 \%$ & 19 & $63.3 \%$ & 24 & $80.0 \%$ & \\
\hline Total & 11 & $36.7 \%$ & 19 & $63.3 \%$ & 30 & $100.0 \%$ & \\
\hline
\end{tabular}

Source: 2017 primary data

From the results of the analysis in table 6 it can be seen that out of 30 respondents, there were $6(20.0 \%)$ respondents with a level of lack of knowledge about pill type contraception and $0(0.0 \%)$ respondents with a low level of knowledge about injectable type contraception, while $5(16.7 \%)$ respondents had the level of knowledge of both pill type contraception and $19(63.3 \%)$ respondents had a good level of knowledge about injectable type contraception.

This means that there is a relationship of knowledge to the selection of contraceptives in couples of childbearing age (EFA) in Tabang Village, Bolong Village, Kec. Walenrang Utara Kab.Luwu.

Relationship between the level of education of respondents to the selection of contraceptives.

Table 7

The relationship between Education Level and the Selection of Contraception Devices in Fertile Age Couples (PUS)

\begin{tabular}{|c|c|c|c|c|c|c|c|}
\hline \multirow{3}{*}{ Education } & \multicolumn{4}{|c|}{ Contaception } & \multicolumn{2}{|c|}{ Total } & \multirow{3}{*}{$\begin{array}{c}\text { P. } \\
\text { Value }\end{array}$} \\
\hline & \multicolumn{2}{|c|}{ Pill } & \multicolumn{2}{|c|}{ Ijection } & \multirow[b]{2}{*}{$\mathrm{N}$} & \multirow[b]{2}{*}{$\%$} & \\
\hline & $\mathrm{N}$ & $\%$ & $\mathrm{~N}$ & $\%$ & & & \\
\hline Basic & 6 & $20.0 \%$ & 0 & $0.0 \%$ & 6 & $20.0 \%$ & .001 \\
\hline Middle & 5 & $16.7 \%$ & 19 & $63.3 \%$ & 24 & $80.0 \%$ & \\
\hline Total & 11 & $36.7 \%$ & 19 & $63.3 \%$ & 30 & $100.0 \%$ & \\
\hline
\end{tabular}

Source: 2017 primary data

Table 7 analysis shows that out of 30 respondents, there were $6(20.0 \%)$ respondents who had a basic education level who chose pill type contraception and $0(0.0 \%)$ respondents who chose injecting type contraception while there were $5(16.7 \%)$ respondents with education level medium who chose pill type contraception and 19 (63.3\%) who choose injection type contraception.

This means that there is an educational relationship with the selection of contraceptives in couples of childbearing age (pus) in Tabang Village, Bolong Village, Kec. Walenrang Utara Kab.Luwu. 


\section{Discussion}

\section{Husband Support with the Selection of Contraception Devices in Fertile Age Couples}

From the results of the above research, it is explained that from several factors that have been processed which shows the relationship between husband's support for the selection of contraceptives with a percentage of $23.3 \%$. The results of this study is in accordance with what was done by (Anita Lontaan), showed that there was a relationship between the participation of husband/wife with the selection of contraceptives with the chi-square test value $=0.000(\rho<0.05)^{[3]}$. In accordance with Suparyanto's opinion, namely in implementing family planning, husband's support is needed. As it is known that in Indonesia, the husband's decision to allow his wife is an important decision for the wife to use contraception. If the husband does not allow or support, only a few wives dare to keep the contraception[4]. The husband's support greatly influences decision-making using or not and what method will be used.

According to the assumption of the researchers by looking at the results of the data management showed that respondents did not get husband's support in the selection of contraceptive methods so that most respondents chose injectable type contraception methods, because husbands do not allow wives to use contraception only a few wives dare to use the contraceptive method. Support from the husband in the use of contraception is very necessary because without the support of the husband, the feeling of comfort to use contraception will not be obtained, in choosing a contraceptive method a husband and wife discuss or consider together to choose the best contraceptive method that is mutually agreed upon, work together in use of contraception, pay attention to danger signs of contraceptive use and bear the costs for contraceptive use.

\section{Knowledge with the selection of contraceptives in couples of childbearing age (EFA)}

From the results of the study, it can be seen that respondents with less knowledge level are $6(20.0 \%)$ while respondents with a good level of knowledge are $24(80.0 \%)$ respondents with a value ( $p$ value $=0.01)$. This shows that there is a relationship between the level of knowledge of respondents with the selection of contraceptive methods.

The results of this study are in accordance with the research conducted[4]. Known results are 116 (99.1\%) respondents who have a low level of knowledge and there are 116 (79.5\%) respondents who have a high level of knowledge. The results of the analysis using chi-square test obtained p value $=0,000(p<0,05)$, then the null hypothesis is rejected, means there is a relationship between knowledge and the selection of contraceptives[5].

The results of this study can also be strengthened by the results of research conducted (by Samira Sri Ayunda) where the results obtained from 36 respondents $(100 \%)$ who were highly knowledgeable, using effective contraceptive methods as many as 2 respondents (61.1\%) and from 34 respondents (100\%) who have low knowledge, using simple contraceptive methods as many as 23 respondents (67.6\%). After the statistical test was obtained $\mathrm{P}$-value $=0.030(\mathrm{P}<0.05)$, so the alternative hypothesis $(\mathrm{Ha})$ that was enforced was acceptable, namely the existence of a relationship between knowledge and the selection of contraceptive methods[5].

In accordance with the opinion of BKKBN, knowledge of contraceptives in the community is already familiar, especially to mothers regarding contraceptive contraception. They do not know what to talk about, but the knowledge that is already available to the public is limited to knowing, if they feel they need to know more. Regarding contraceptives, they will go to the health care center[6].

According to the assumption of the researchers by looking at the results of the data management, it shows that respondents were highly knowledgeable in the selection of contraceptive methods so that most respondents chose injectable type contraception methods.

\section{Education with the selection of contraceptives in couples of childbearing age (EFA)}

From the results of the study, it can be seen that respondents with basic education are 6 (20.0) while respondents with secondary education are $24(80.0)$ respondents with $\mathrm{p}$ value $=0.01$ which means that there is a relationship between education level and type selection contraception used.

This is also relevant with the research by, the results indicated that the respondents of higher education levels prefer the Long-Term Contraception Method compared to respondents of the basic 
education level, the results of statistical analysis showed the value of $\rho=0.000(\rho<0.05)$, meaning that there is a relationship between education level with Contraception Selection[3].

In accordance with the opinion of Mubarak and Chayatin suggests education means guidance given by someone to others to something that they can understand. It is undeniable that the higher one's education, the easier for them to receive information[7]. In the end, the more knowledge he has, on the contrary, if someone has a low level of education, it will hinder the development of one's attitude towards acceptance, information and newly introduced values.

According to the assumptions of the researchers by looking at the results of the data management, it is shown that respondents with secondary education in the selection of contraceptive methods most respondents chose the method of injection contraception. Education will affect a person's attitude in decision-making because the higher the level of education will be more rational in making decisions, this will also apply in making decisions to choose an repetition appropriate and effective contraceptive method.

\section{Conclusion and Suggestion}

Based on the results of the research conducted, it can be concluding as in the following:

Out of 30 respondents, there were 7 (23.3\%) respondents who did not receive husband support using pill type contraception while $4(13.3 \%)$ received husband support, while those who did not receive husband support using injectable type contraception, there were $0(0.0 \%)$ respondents and who received husband's support using injectable type contraception there were $19(63.3 \%)$ respondents. Out of 30 respondents, there were $6(20.0 \%)$ respondents with a level of lack of knowledge about pill type contraception and 0 $(0.0 \%)$ respondents with a level of lack of knowledge about injectable type contraception, while $5(16.7 \%)$ respondents had a good level of knowledge about type contraception pills and 19 (63.3\%) respondents had a good level of knowledge about injectable type contraception. Out of 30 respondents there were $6(20.0 \%)$ respondents who had basic education who chose pill type contraception and $0(0.0 \%)$ respondents who chose injecting type contraception while there were $5(16.7 \%)$ respondents with secondary education who chose contraception type of pill and $19(63.3 \%)$ who chose injectable type contraception. From the statistical test it was found that there was a relationship between husband's support for the selection of contraceptive types, there was a relationship of knowledge to the selection of contraceptive types, and there was a relationship to the level of education towards the selection of contraceptive types.

This research could be completed because of the support of the institution and the Kunia Jaya Persada Foundation where one was for the development of lecturers and for the benefit of society in general. This research gets funding from the institution by submitting a research proposal. This research will also not be carried out if there is no support from the northern Walenrang community to be willing to become respondents and health centers and agencies in the local area for every contribution in the smoothness of this research.

\section{References}

[1] Republic of Indonesia Ministry of Health. Indonesian Health Profile 2014 [cited 2019 Apr 15. Available from http://www.depkes.go.id/resources/download/pusdatin/profil-kesehatanindonesia/profil-kesehatan-indonesia-2014.pdf

[2] Bkkbn, South Sulawesi Province. Profile of the South Sumatra Province South Sulawesi Province: Bkkbn South Sulawesi Province. (2012). Download from www.depkes.go.id

[3] Anita Lontan. Factors related to the choice of contraceptive couples in childbearing age at the puskesmas in the regency of Talaud. (2014). Accessed from www.poltekkes-manado.ac.id

[4] Anggio. (2012). Factors that influence the choice of contraception. Accessed from www.jornal.stikestelogorejo.ac.id.

[5] Suparyanto. Basic Concept of Family Planning. 2011. http: // by-one. blogspot. com / 2011/04 / concept-base-kb-family-planning. html accessed on July 8, 2017.

[6] Sriayu Bintansari S Factors related to the selection of contraceptive devices in the working area of the pundata baji health center. (2015). Accessed from http://repositoryunhas.ac.id

[7] Bkkbn. Profile of Population and Development in Indonesia. (2015). Jakarta: BKKBN. 